Maciej CIOŁEK ${ }^{1}$

\title{
QUESTIONING MIND IN ACCOUNTING STUDENTS - AN EXPERIMENTAL STUDY
}

\begin{abstract}
In the ongoing auditing debate on professional skepticism, 'questioning mind' has focused a respectable attention. With questioning mind, auditors are not satisfied with simple answers and look deeper until their beliefs are formed. It is even stated that: "professional skepticism requires an ongoing questioning of whether the information and evidence obtained suggests that a material misstatement due to fraud has occurred". The purpose of this study is to examine whether university accounting programs shape the questioning mind of the students to a greater extent comparing other university programs in the field of economy. For this purpose I conducted an experimental study using one of the skepticism measures, the Hurtt Professional Skepticism Scale - HPSS. It involved 432 students of Poznan University of Economics following accounting program and management program (control group). The results showed that only ACCA accredited program in accounting increased the level of 'questioning mind' significantly comparing to standard academic program in accounting and management program. The robustness analysis showed that gender of subjects and length of professional experience had no statistically significant impact on results. On the contrary, the experience itself had an impact on results
\end{abstract}

Keywords: questioning mind, professional skepticism, accounting education, accounting students, auditing education.

\section{INTRODUCTION}

Questioning mind along with a critical assessment of evidence are being defined as main attitudes that characterize professional skepticism. Both literature ${ }^{2}$ and professional

\footnotetext{
${ }^{1}$ Maciej Ciołek, PhD, Poznan University of Economics and Business, Department of Accounting, Niepodległości 10, 61-875 Poznań; e-mail: maciej.ciolek@ue.poznan.pl.

Dr Maciej Ciołek, adiunkt w Katedrze Rachunkowości, Uniwersytet Ekonomiczny w Poznaniu, al. Niepodległości 10, 61-875 Poznań; e-mail: maciej.ciolek@ue.poznan.pl.

2 J.J. McMillan, R.A. White, Auditors' belief revisions and evidence search: The effect of hypothesis frame, confirmation and professional skepticism, "The Accounting Review", No. 68 (3), 1993, p. 443-465; S.K. Asare, L. McDaniel, The effect of familiarity with the preparer and task complexity on the effectiveness of the audit review process, "The Accounting Review", No. 71, April 1996, p. 139-159; M. Peecher, The influence of auditors' justification processes on their decisions: A cognitive model and experimental evidence, "Journal of Accounting Research", issue (Spring), 1996, p. 125-140; M. Shaub, J. Lawrence, Ethics, experience and professional skepticism: A situational analysis, Behavioral Research in Accounting, issue 8 (Supplement), 1996, p. 124-157; B.H. Anderson, M.J. Maletta, Primacy Effects and the Role of Risk in Auditor Belief-Revision Processes, AUDITING: “A Journal of Practice \& Theory”, March 1999, Vol. 18, No. 1, p. 75-89; F. Choo, K. Tan, Instruction, skepticism, and accounting students' ability to detect frauds in auditing, "The Journal of Business Education", No 1, Fall 2000, p. 72-87; J.M. Mueller, J.C.
} 
standards ${ }^{3}$ is at the foundation of the auditing and accounting profession. Moreover, such questioning attitude and behavior is "essential to the performance of effective audits" and "is required in every aspect of every audit by every auditor working on the audit".

Although both regulators and researchers emphasize the importance of employing the appropriate level of questioning mind in accounting and auditing procedures, we still know little about this characteristic itself. Various papers in accounting equate this notion with such terms as suspicion, disbelief, doubt, all of which have some aspects of questioning ${ }^{5}$. In other fields the questioning mind is being underlined as an essential trait of a skeptical attitude as well. For example, in philosophy Fogelin ${ }^{6}$ defines a skeptical person as the one who "calls things into question". McGinn states that a skeptic questions everything, even her or his own judgments ${ }^{7}$ and Kurtz points out that "doubt

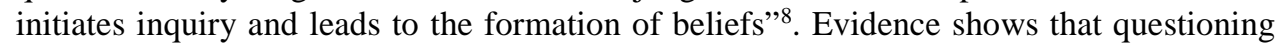
mind of an auditor is trait particularly important when examining fraud risks and is positively correlated with detecting material misstatements resulting from fraud ${ }^{9}$.

Anderson, Decision aids for generating analytical review alternatives: The impact of goal framing and audit-risk level, "Behavioral Research in Accounting", No. 14, 2002, p. 157-177; J.M. Rose., Attention to evidence of aggressive financial reporting and intentional misstatement judgments: Effects of experience and trust, "Behavioral Research in Accounting", No. 19, 2007, p. 215-229; M. Nelson, A model and literature review of professional skepticism in auditing, Auditing: "A Journal of Practice \& Theory", No. 28 (2), 2009, p. 1-34; R.K. Hurtt, Development of a scale to measure professional skepticism, Auditing: “A Journal of Practice \& Theory”, issue 29 (1), 2010, p. 149-171; R.K. Hurtt, H. Brown-Liburd, Ch. Earley, G. Krishnamoorthy, Research on Auditor Professional Skepticism- Literature Synthesis and Opportunities for Future Research, AUDITING: "A Journal of Practice \& Theory", No. 32 (Sp. 1), 2013, p. 45-97; M. Ciołek, Professional skepticism in auditing and its characteristics, Global Challenges of Management Control and Reporting, Prace Naukowe Uniwersytetu Ekonomicznego we Wrocławiu, No. 474, 2017, p. 33-41.

3 AICPA, Due Care in the Performance of Work. Statement on Auditing Standards No. 1, American Institute of Certified Public Accountants, New York 1997; Public Company Accounting Oversight Board (PCAOB), An Audit of Internal Control over Financial Reporting Performed in Conjunction with an Audit of Financial Statements, PCAOB Auditing Standard, No. 2, 2004; AICPA, The Confirmation Process, Statement on Auditing Standards No. 67, New York 1992; AICPA, Understanding the Entity and Its Environment and Assessing the Risks of Material Misstatement, Statement on Auditing Standards No. 109, New York 2006; IAASB, ISA 200 Overall Objectives of the Independent Auditor and the Conduct of an Audit in Accordance with International Standards on Auditing, The International Auditing and Assurance Standards Board, New York, 2010; IAASB, ISA 240 The Auditor's Responsibilities Relating to Fraud in an Audit of Financial Statements, The International Auditing and Assurance Standards Board, New York 2010.

${ }^{4} \mathrm{M}$. Baumann, Remarks Concerning PCAOB Developments presented at the AICPA Conference on Current SEC and PCAOB Developments, December 4, Washington, DC, 2012, http://pcaobus.org/ News/Speech/Pages/12042012_AICPA.aspx.

${ }^{5}$ M. Nelson, A model..., p. 1-34.

${ }^{6}$ R.J. Fogelin, Pyrrhonian Reflections on Knowledge and Justification, Oxford University Press, New York, 1994.

${ }^{7}$ M. McGinn, Sense and Certainty: A Dissolution of Scepticism, Basil Blackwell Inc., New York 1989.

${ }^{8}$ P. Kurtz, The New Skepticism: Inquiry and Reliable Knowledge, Prometheus Books, Buffalo, New York 1992.

9 J.H. Grenier, Encouraging Professional Skepticism in the Industry Specialization Era: A DualProcess Model and an Experimental Test, Dissertation at the University of Illinois, 2010; 
According to most recent research only a small percentage of corporate frauds are being detected by auditors ${ }^{10}$.

The main goal of this paper is to answer the question whether university accounting program stimulates positively the mean level of questioning mind trait in accounting students comparing to the students of other programs in the field of economy. It is an important issue since both accounting and auditing profession require this trait to be above the average. Plumlee et al. showed that it is possible to increase the level of skeptical thinking in auditors due to proper training ${ }^{11}$. So, does a 3-year undergraduate and 2-year graduate accounting programs shape students' questioning mind?

In order to answer this question I conducted an experiment measuring individual trait questioning mind using the Hurtt professional skepticism scale ${ }^{12}$. I surveyed first-year undergraduate and last year graduate accounting students (researched groups) and management students (control groups) using the questionnaire provided by Hurtt. I compared the change in questioning mind level for both groups during 4 years of studying and provided robustness analysis controlling independent variables such as: gender and professional experience (type and length). The results of the study indicate that there are no statistically significant differences in change of questioning mind trait mean levels between researched group and control group. However, distinguishing between standard academic program in accounting and ACCA accredited program in accounting leads to different conclusions. The change in the level of questioning mind for accounting students following ACCA accredited program is statistically positive comparing to both management students (control group) and accounting students following standard academic program.

I have also found no evidence that gender has an impact on the change in the level of the trait for any of the surveyed groups. However, the impact of professional experience on the mean scores is statistically significant. After recalculating means and standard deviations which allowed to control for this independent variable the results show that it significantly affects the change in the level of questioning mind trait. Subjects from both researched and control groups who declared professional experience other than work in auditing companies, accounting or financial departments significantly increased their mean level of questioning mind trait measured with Hurtt's scale in comparison to the subjects with no professional experience.

\section{DATA COLLECTION}

I collected data to test the hypotheses using a part of questionnaire developed by Hurtt supplemented with demographic data form (see the Appendix A). The researched subjects were first-year undergraduate and final-year graduate accounting students at Poznan

N. Harding, K.T. Trotman, Enhancing professional skepticism via the fraud brainstorming discussion outcomes, Working Paper, University of Melbourne, 2011; B. McCormack, T. Watts, Acquistion of Auditing Skills: Enhancing Skepticism, Problem Solving and Beyond on the Fraud Continuum, Working Paper, University Of Wollongong, 2011.

${ }^{10}$ KPMG, KPMG Fraud Survey 2009 Report, Kuala Lumpur, 2009; Zeune G.D., Fraud: It is your job!, Michigan CPA, no 48(4), 1997, p. 26-31.

11 D. Plumlee, B.A. Rixom, A.J. Rosman, Training Auditors to Think Skeptically, Working paper, The University of Utah and University of Connecticut, 2012.

${ }^{12}$ R.K. Hurtt, Development of a scale..., p. 149-171. 
University of Economics and Business. As a control group I used management students following separate program within the same faculty. The selected university is one of the oldest, most prestigious schools of economics in Poland and was classified in 2017 as "Top Business School with significant international influence" by Eduniversal rating agency.

The university offers undergraduate and two graduate accounting programs, among which, one is accredited by the Association of Chartered Certified Accountants. Graduates from these two programs are usually targeted by accounting and auditing firms (including the Big 4), however, students following the ACCA accredited program are exempt from 9 out of 14 exams required to obtain certificate. In most cases they are certified within one year after graduating. It is also important to mention that there are differences in course materials and teaching methods used in both graduate accounting programs. Within accredited program around 60-70\% course materials as well as final exam tests are provided by ACCA. This implies applying consistent teaching methods, which are somehow different than ones being used under standard university graduate accounting courses. Hence, the students following ACCA accredited program are occasionally separated as a subgroup in the results section.

To ensure that the researched subjects received the same information, all the relevant instructions were provided in a written format as a part of the questionnaire. The surveying process was conducted between November 15, 2017 and November 30, 2017 after being granted a permission for using Hurtt's questionnaire from AAA (American Accounting Association). I personally administered most of the surveying process which was performed during the first or last 30 minutes of the selected lectures. The survey took approximately 20-25 minutes to complete. However, there was no specified time limit. All of the researched students were instructed that taking part in the survey is voluntary and that the refusal meets no consequences for them.

\section{DATA COLLECTION}

The survey form used in the research developed by Hurtt along with the instructions was originally designed in English. In order to ensure the accuracy of the research instrument translation into Polish, consistent with prior studies, the recursive translation procedures were used ${ }^{13}$. The original questionnaire and instructions provided by Hurtt were initially translated into Polish. The translated version was then retranslated back into English by a certified language lecturer who is proficient in both English and Polish (native language). After a forward-backward procedure an identified discrepancies between the English and the Polish versions were discussed jointly within a group of three certified English language lecturers. This process was replicated recursively three times until all discrepancies were eliminated. The final version of translated questionnaire and instructions (section B) were then supplemented with demographic data form (section A). Such a research instrument

${ }^{13}$ G.T.M. Hult, D.J. Ketchen, D.A. Griffith, C.A. Finnegan, T. Gonzalez-Padron, N. Harmancioglu, Y. Huang, M..B. Talay, S.T. Cavusgil, Data equivalence in cross-cultural international business research: Assessment and guidelines, "Journal of International Business Studies", No. 39 (6), 2008, p. 1027-1044; S.X. Ying, C. Patel, Skeptical Judgments and Self-Construal: A Comparative Study between Chinese Accounting Students in Australia and China, "Journal of International Accounting Research", Vol. 15, No. 3 (Fall), 2016, p. 97-111. 
was pre-tested by group of 12 academics from the Department of Finance and Business Accounting of Poznan University of Economics and Business.

Section A of the questionnaire form collects the demographic data of the researched subjects. They are further used as a control variables in the analysis of the data provided by the students in section B. The respondents were asked to provide the following information: age, gender, professional experience, course type they are actually following at the university (bachelor/master) and program field (accounting/management). The professional experience form consist of 4 possible choices: Accounting firm/Accounting department, Auditing company, Financial department of a company, Other professional experience. The researched students marked their area of work experience and provide information about length of it (in years). Additionally, they were instructed not to include any summer jobs, odd jobs and part-time jobs into "other professional experience" category. In section B of the questionnaire participants were asked to answer questions on six-point Likert scale, which measure the dependent variable.

Students who agreed to take a part in the research were asked to provide all the demographic data in the section A and mark answers to all the statements in section B. However, the questionnaires filled in incompletely were not automatically excluded from the analysis. They were included into the analyses if the data provided are sufficient for testing a particular hypothesis.

The pilot test suggested that the translation of the questionnaire is accurate as the preliminary results are similar to the ones obtained by Hurtt with Professional Auditors ${ }^{14}$.

\section{RESULTS}

The researched subjects consist of two main groups: first-year undergraduate accounting students and final-year graduate accounting students, as well as two control groups: first-year undergraduate management students and final-year graduate management students. A total of 432 responses were received: 146 (at the response rate 90 percent) and 95 (at the response rate 84 percent) from accounting students and 84 (at the response rate 93 percent) and 107 (at the response rate 88 percent) from management students, respectively. The demographic details of respondents are reported in Table 1.

For the 1st year undergraduate accounting program most of the researched subject were females $(63.0 \%)$, at the age of 20 or younger $(95.9 \%)$ with no work experience $(78,1 \%)$. Comparable demographic statistics were identified for the control group, in which respondents consist in $50 \%$ of females, at the age of 20 or younger $(96.4 \%)$ without work experience $(73.8 \%)$. At both groups approximately $1 \%$ had any professional experience in accounting or auditing.

The second researched group of subjects were final-year graduate accounting students. This group was highly dominated by females (83.2\%), which is not unusual as around $90 \%$ of certified accountants in Poland are women ${ }^{15}$. Most of the researched subjects in this group were 23 years old or above $(94.7 \%)$ with work experience $(77.9 \%)$. Note that about

${ }^{14} 6$ out of 12 academics from the Accounting Department who agreed to take a part in the pilot test are actually certified Professional Auditors.

${ }^{15}$ M. Masztalerz, Czy rachunkowość w Polsce jest kobieta?, Współczesne problemy w nauce, dydaktyce i praktyce rachunkowości, Prace Naukowe Uniwersytetu Ekonomicznego we Wrocławiu, 2017 , No. 503, p. 326-335 
half $(46.4 \%)$ of the final-year graduate accounting students had professional experience in accounting or auditing. In contrast, the control group was not so dominated by the females (59.8\%), had similar age structure, with most subjects being 23 years old or above $(99.1 \%)$, and comparable percentage of subjects had work experience (79.4\%). However, only very few of the subjects from the control group had any professional experience in accounting $(2.8 \%)$ which makes the biggest difference in contrast to final-year graduate accounting students. To control for the effects of the demographic variables, gender, age, work experience (length and profile), these measures were used as independent variables in the hypotheses testing.

Table 1. Demographic data of the researched subjects

\begin{tabular}{|c|c|c|c|c|c|c|c|c|c|c|}
\hline \multirow[b]{3}{*}{ Gender } & \multicolumn{4}{|c|}{ 1st year undergraduate } & \multicolumn{4}{|c|}{ Final-year graduate } & \multirow{2}{*}{\multicolumn{2}{|c|}{ Total }} \\
\hline & \multicolumn{2}{|c|}{$\begin{array}{c}\text { Accounting } \\
\text { students }\end{array}$} & \multicolumn{2}{|c|}{$\begin{array}{c}\text { Management } \\
\text { students }\end{array}$} & \multicolumn{2}{|c|}{$\begin{array}{c}\text { Accounting } \\
\text { students }\end{array}$} & \multicolumn{2}{|c|}{$\begin{array}{c}\text { Management } \\
\text { students }\end{array}$} & & \\
\hline & $\mathbf{n}$ & $\%$ & $\mathbf{n}$ & $\%$ & $\bar{n}$ & $\%$ & $\mathbf{n}$ & $\%$ & $\mathbf{n}$ & $\%$ \\
\hline Female & 92 & $63.0 \%$ & 42 & $50.0 \%$ & 79 & $83.2 \%$ & 64 & $59.8 \%$ & 277 & $64.1 \%$ \\
\hline Male & 54 & $37.0 \%$ & 42 & $50.0 \%$ & 16 & $16.8 \%$ & 43 & $40.2 \%$ & 155 & $35.9 \%$ \\
\hline Total & 146 & $100 \%$ & 84 & $100 \%$ & 95 & $100 \%$ & 107 & $100 \%$ & 432 & $100 \%$ \\
\hline Age & $\mathbf{n}$ & $\%$ & $\mathbf{n}$ & $\%$ & $n$ & $\%$ & n & $\%$ & $\mathbf{n}$ & $\%$ \\
\hline 19 and Under & 123 & $84.2 \%$ & 69 & $82.1 \%$ & 0 & $0.0 \%$ & 0 & $0.0 \%$ & 192 & $44.4 \%$ \\
\hline 20 & 17 & $11.6 \%$ & 12 & $14.3 \%$ & 0 & $0.0 \%$ & 0 & $0.0 \%$ & 29 & $6.7 \%$ \\
\hline 21 & 4 & $2.7 \%$ & 2 & $2.4 \%$ & 0 & $0.0 \%$ & 0 & $0.0 \%$ & 6 & $1.4 \%$ \\
\hline 22 & 1 & $0.7 \%$ & 0 & $0.0 \%$ & 5 & $5.3 \%$ & 1 & $0.9 \%$ & 7 & $1.6 \%$ \\
\hline 23 & 1 & $0.7 \%$ & 1 & $1.2 \%$ & 66 & $69.5 \%$ & 63 & $58.9 \%$ & 131 & $30.3 \%$ \\
\hline 24 and Over & 0 & $0.0 \%$ & 0 & $0.0 \%$ & 24 & $25.3 \%$ & 43 & $40.2 \%$ & 67 & $15.5 \%$ \\
\hline Total & 146 & $100 \%$ & 84 & $100 \%$ & 95 & $100 \%$ & 107 & $100 \%$ & 432 & $100 \%$ \\
\hline Mean & & & & 9.1 & & 3.2 & & & & \\
\hline Standard dev. & & & & 8 & & .6 & & & & \\
\hline $\begin{array}{c}\text { Professional } \\
\text { experience }\end{array}$ & $\mathbf{n}$ & $\%$ & $\mathbf{n}$ & $\%$ & $\mathbf{n}$ & $\%$ & $\mathbf{n}$ & $\%$ & $\mathbf{n}$ & $\%$ \\
\hline in accounting & 2 & $1.4 \%$ & 1 & $1.2 \%$ & 41 & $43.2 \%$ & 3 & $2.80 \%$ & 47 & $10.9 \%$ \\
\hline in auditing & 0 & $0.0 \%$ & 0 & $0.0 \%$ & 3 & $3.2 \%$ & 0 & $0.00 \%$ & 3 & $0.7 \%$ \\
\hline in other areas & 30 & $20.5 \%$ & 21 & $25.0 \%$ & 30 & $31.6 \%$ & 82 & $76.60 \%$ & 163 & $37.7 \%$ \\
\hline no experience & 114 & $78.1 \%$ & 62 & $73.8 \%$ & 21 & $22.1 \%$ & 22 & $20.60 \%$ & 219 & $50.7 \%$ \\
\hline Total & 146 & $100 \%$ & 84 & $100 \%$ & 95 & $100 \%$ & 107 & $100 \%$ & 432 & $100 \%$ \\
\hline
\end{tabular}

H1: University accounting programs do not shape significantly stronger questioning mind level in students (measured with HPSS) in comparison to the other programs in the field of economy

In hypothesis 1 , it is stated that there is no statistically significant difference in change of questioning mind level measured with HPSS between students doing accounting programs and students doing other programs in the field of economy. The descriptive 
statistic on questioning mind level measured with HPSS are reported in Table 2. The mean scores achieved by first-year bachelor (undergraduate) accounting students and control group (management students) are statistically indifferent $(\mathrm{p}<0.05)$. Table 2 shows also, that consistent with the expectation, the mean score of final year master students doing accounting program do not differ from the mean score of the control group ( $p<0.05)$. Although, mean levels of the trait measured with HPSS in both groups have changed during 4 years of education, the accounting program has no significant impact on relative change in this level compared to the control group. Therefore, we can acknowledge H1 to be confirmed.

H1a: University accounting programs accredited by external accounting association of professionals do not shape significantly stronger questioning mind level in students (measured with HPSS) in comparison to the standard academic accounting programs

In H1a I distinguish between students of two different master programs in accounting. I also predict that none of these two programs have significant impact on change of students' questioning mind level comparing one to another. As there is only one accounting program on the undergraduate level and both groups have equal initial mean score, the hypothesis is confirmed if there is no statistically significant difference in mean scores of these two groups at final year graduate level. Table 2 shows that H1a may be initially rejected as the

Table 2. Descriptive Statistics of Questioning Mind Level Measured with HPSS

\begin{tabular}{|c|c|c|c|c|c|c|c|c|c|}
\hline H1 & \multicolumn{3}{|c|}{ Accounting Students } & \multicolumn{3}{|c|}{ Management Students } & \multicolumn{3}{|c|}{ Significance } \\
\hline Subjects & $\mathrm{n}$ & $\begin{array}{l}\text { Mean } \\
\text { Score }\end{array}$ & $\begin{array}{c}\text { Standard } \\
\text { Dev. }\end{array}$ & $\mathrm{n}$ & $\begin{array}{l}\text { Mean } \\
\text { Score }\end{array}$ & $\begin{array}{l}\text { Standard } \\
\text { Dev. }\end{array}$ & $\mathrm{t}$ & $\mathrm{p}$ & $\begin{array}{c}\text { Test } \\
\text { Result }\end{array}$ \\
\hline 1st year undergrad. & 145 & 10.2 & 2.6 & 81 & 9.9 & 2.7 & 0.82 & $1.97 *$ & Conf. \\
\hline 2nd year graduate & 93 & 10.3 & 2.5 & 107 & 10 & 2.2 & 0.9 & $1.97 *$ & Conf. \\
\hline Mean Score change & 0.1 & & & 0.1 & & & & & \\
\hline Mean Score change & $1.00 \%$ & & & $1.00 \%$ & & & & & \\
\hline H1a & \multicolumn{3}{|c|}{$\begin{array}{c}\text { Accounting Students } \\
\text { (standard) }\end{array}$} & \multicolumn{3}{|c|}{$\begin{array}{c}\text { Accounting Students } \\
(\text { ACCA })\end{array}$} & \multicolumn{3}{|c|}{ Significance } \\
\hline Subjects & $\mathrm{n}$ & $\begin{array}{l}\text { Mean } \\
\text { Score }\end{array}$ & $\begin{array}{c}\text { Standard } \\
\text { Dev. }\end{array}$ & $\mathrm{n}$ & $\begin{array}{l}\text { Mean } \\
\text { Score }\end{array}$ & $\begin{array}{l}\text { Standard } \\
\text { Dev. }\end{array}$ & $\mathrm{t}$ & $\mathrm{p}$ & $\begin{array}{c}\text { Test } \\
\text { Result }\end{array}$ \\
\hline 1st year under grad. & 145 & 10.2 & 2.6 & 145 & 10.2 & 2.6 & - & - & - \\
\hline 2nd year graduate & 69 & 9.9 & 2.5 & 26 & 11.3 & 2.3 & 2.49 & $1.98 *$ & Rejected \\
\hline Mean Score change & -0.3 & & & 1.1 & & & & & \\
\hline Mean Score change & $-2.90 \%$ & & & $10.80 \%$ & & & & & \\
\hline H1b & \multicolumn{3}{|c|}{ Management Students } & \multicolumn{3}{|c|}{$\begin{array}{c}\text { Accounting Students } \\
(\mathrm{ACCA})\end{array}$} & \multicolumn{3}{|c|}{ Significance } \\
\hline Subjects & $\mathrm{n}$ & $\begin{array}{l}\text { Mean } \\
\text { Score }\end{array}$ & $\begin{array}{l}\text { Standard } \\
\text { Dev. }\end{array}$ & $\mathrm{n}$ & $\begin{array}{l}\text { Mean } \\
\text { Score }\end{array}$ & $\begin{array}{c}\text { Standard } \\
\text { Dev. }\end{array}$ & $\mathrm{t}$ & $\mathrm{p}$ & $\begin{array}{c}\text { Test } \\
\text { Result }\end{array}$ \\
\hline 1st year under grad. & 81 & 9.9 & 2.7 & 145 & 10.2 & 2.6 & 0.82 & $1.97 *$ & Conf. \\
\hline 2nd year graduate & 107 & 10 & 2.2 & 26 & 11.3 & 2.3 & 2.68 & $2.61 * *$ & Rejected \\
\hline Mean Score change & 0.1 & & & 1.1 & & & & & \\
\hline Mean Score change & $1.00 \%$ & & & $10.80 \%$ & & & & & \\
\hline
\end{tabular}

*, ** Significant at $\mathrm{p}<0.05$ and $\mathrm{p}<0.01$, respectively (two-tailed). 
mean score differs significantly $(\mathrm{p}<0.05)$. What is also interesting is that students of ACCA accredited accounting program increased their initial mean score by $10.8 \%$ while their colleagues doing standard academic master program in accounting decreased their mean score since first-year undergraduate by $(-2.9 \%)$.

H1b: University accounting programs accredited by external accounting association of professionals do not shape significantly stronger questioning mind level in students (measured with HPSS) to the other programs in the field of economy

Under H1b I expect that master accounting program accredited by ACCA has no significant impact on the change of the questioning mind level measured with HPSS compared to the control group. As the mean scores of these two groups differ significantly $(\mathrm{p}<0.01)$ at final year master level and are indifferent $(\mathrm{p}<0.05)$ at first-year bachelor level, the hypothesis isn't initially supported by the results. I also performed robustness analysis to confirm or disconfirm the impact of independent variables on the test results of the hypotheses H1, H1a and H1b. Firstly, I analyzed whether the gender significantly affects the mean score and standard deviation of collected questionnaire results.

H2: There is no statistically significant difference in mean level of questioning mind trait (measured with HPSS) between females and males in the researched groups and control groups

In H2 I expect that there is no relation between gender and the level of questioning mind trait measured with HPSS and in consequence the gender structure of researched groups does not affect significantly the test results of $\mathrm{H} 1, \mathrm{H} 1 \mathrm{a}$ and $\mathrm{H} 1 \mathrm{~b}$. Table 3 shows that the mean score of males at first-year undergraduate level and final year graduate level insignificantly $(\mathrm{p}<0.05)$ differs from the mean score of females. The obtained results support $\mathrm{H} 2$ and controlling for gender was unnecessary.

Table 3. The Impact of Gender on H1, H1a and H1b

\begin{tabular}{|l|c|c|c|c|c|c|c|c|c|}
\hline & \multicolumn{3}{|c|}{ Females } & \multicolumn{3}{c|}{ Males } & \multicolumn{3}{c|}{ Significance } \\
\hline Subjects and means & $\mathrm{n}$ & $\begin{array}{c}\text { Mean } \\
\text { Score }\end{array}$ & $\begin{array}{c}\text { Standard } \\
\text { Dev. }\end{array}$ & $\mathrm{n}$ & $\begin{array}{c}\text { Mean } \\
\text { Score }\end{array}$ & $\begin{array}{c}\text { Standard } \\
\text { Dev. }\end{array}$ & $\mathrm{t}$ & \multicolumn{2}{c|}{$\begin{array}{c}\text { Test } \\
\text { Result }\end{array}$} \\
\hline 1st year under grad. & 132 & 9.8 & 2.6 & 94 & 10.5 & 2.7 & 1.96 & 1.97 & Confirmed \\
\hline 2nd year graduate & 142 & 10 & 2.4 & 58 & 10.5 & 2 & 1.4 & 1.97 & Confirmed \\
\hline Mean Score change & \multicolumn{3}{|c|}{0.2} & \multicolumn{3}{c|}{$0.00 \%$} & & & \\
\hline Mean Score \% change & \multicolumn{3}{|c|}{$2.00 \%$} & \multicolumn{3}{c|}{} & & \\
\hline
\end{tabular}

H3: There is no statistically significant difference in mean level of questioning mind trait (measured with HPSS) between groups of researched subjects with and without professional experience

In the next stage of the robustness analysis I measured the impact of work experience on the researched subjects questioning mind level. In H3 I expect that such impact exist but it does not affect mean scores significantly. The results show that professional experience does have a significant $(\mathrm{p}<0.005)$ impact on mean score for final year graduate students. Detailed statistics are reported in Table 4. 
Questioning mind in accounting students...

Table 4. The Impact of Professional Experience on H1, H1a and H1b

\begin{tabular}{|l|c|c|c|c|c|c|c|c|c|}
\hline & \multicolumn{3}{|c|}{ No experience } & \multicolumn{3}{c|}{ With experience } & \multicolumn{3}{c|}{ Significance } \\
\hline \hline Subjets and means & $\mathrm{n}$ & $\begin{array}{c}\text { Mean } \\
\text { Score }\end{array}$ & $\begin{array}{c}\text { Standard } \\
\text { Dev. }\end{array}$ & $\mathrm{n}$ & $\begin{array}{c}\text { Mean } \\
\text { Score }\end{array}$ & $\begin{array}{c}\text { Standard } \\
\text { Dev. }\end{array}$ & $\mathrm{t}$ & $\mathrm{p}$ & $\begin{array}{c}\text { Test } \\
\text { Result }\end{array}$ \\
\hline 1st year undergrad. & 172 & 9.9 & 2.7 & 54 & 10.6 & 2.7 & 1.57 & $1.98^{*}$ & Conf. \\
\hline Accounting Dept./Office & & & & 3 & 10.3 & 1.5 & & & \\
\hline Auditing Firm & & & & & & & & & \\
\hline Financial Department & & & & 5 & 10.4 & 3 & & & \\
\hline In Other Areas & & & & 46 & 10.6 & 2.7 & & & \\
\hline & & & & & & & & & \\
\hline 2nd year graduate & 42 & 9.2 & 2.1 & 158 & 10.4 & 2.3 & 2.95 & $2.84 * *$ & Rejected \\
\hline Accounting Dept./Office & & & & 45 & 10.1 & 2.7 & & & \\
\hline Auditing Firm & & & & 3 & 12.3 & 2.1 & & & \\
\hline Financial Department & & & & 4 & 11 & 3.6 & & & \\
\hline In Other Areas & & & & 106 & 10.4 & 2.1 & & & \\
\hline Mean Score change & \multicolumn{7}{|c|}{-0.7} & \multicolumn{7}{|c|}{-0.194} & & & \\
\hline Mean Score \% change & \multicolumn{7}{|c|}{$-7.10 \%$} & \multicolumn{7}{c|}{$-1.80 \%$} & & & \\
\hline
\end{tabular}

$*$, ** Significant at $\mathrm{p}<0.05$ and $\mathrm{p}<0.005$ (two-tailed), respectively

Further analysis shows that the impact of the professional experience on final year students mean scores applies only to both researched subjects group and control group, significant at ( $\mathrm{p}<0.01)$. I also disaggregated professional experience into four components, which were given to the researched subjects as possible choices, in order to verify whether significant differences in mean scores for final year control group apply to any professional experience or only to particular type of it. However, I decided to re-aggregate data collected for the professional experience in Accounting Department or Accounting Office, Auditing Firm and Financial Department into one category (Experience in Accounting, Audit or Finance) as only 8 subjects out of 219 for first-year undergraduate groups claimed to have such a work experience and 8 subjects out of 201 researched at final year graduate declared to have worked in Auditing Firm or Financial Department. I recalculated then means and standard deviations for the new aggregated item "Experience in Accounting, Auditing or Finance" and compared with means scores of subjects with no professional experience and with other professional experience. The dependence indentified earlier is significant $(\mathrm{p}<0.05)$ for both groups only in case of Other Professional Experience in comparison to group with no work experience. In order to control for professional experience independent variable I equalized the professional experience structures of first-year undergraduate groups and adequate final year graduate groups. Firstly, I recalculated mean scores and standard deviations of the final year graduate accounting group and control group according to the professional experience structure of the adequate first-year undergraduate groups. Secondly, I reversed this procedure by recalculating mean scores and standard deviations of the first-year undergraduate group and control group according to the professional experience structure of the adequate final year graduate groups. The results obtained show there are significant differences in mean scores of accounting groups and control groups with equalized professional experience structures. Therefore this independent variable 
has significant impact on $\mathrm{H} 1$. The detailed results of the above analysis are presented in Table 5.

Table 5. The Impact of Professional Experience on H1

\begin{tabular}{|c|c|c|c|c|c|c|c|c|c|}
\hline \multicolumn{10}{|c|}{ Professional experience structure as in 1st year undergraduate } \\
\hline & \multicolumn{3}{|c|}{ Accounting Students } & \multicolumn{3}{|c|}{ Management Students } & \multicolumn{3}{|c|}{ Significance } \\
\hline Subjects and means & $\mathrm{n}$ & $\begin{array}{l}\text { Mean } \\
\text { Score }\end{array}$ & $\begin{array}{c}\text { Standard } \\
\text { Deviation }\end{array}$ & $\mathrm{n}$ & $\begin{array}{l}\text { Mean } \\
\text { Score }\end{array}$ & $\begin{array}{c}\text { Standard } \\
\text { Deviation }\end{array}$ & $\mathrm{t}$ & $\mathrm{p}$ & $\begin{array}{l}\text { Hypothesis } \\
\text { Test Result }\end{array}$ \\
\hline 1st year undergraduate & 145 & 10.2 & 2.6 & 81 & 9.9 & 2.7 & 0.82 & $1.97 *$ & Confirmed \\
\hline 2nd year graduate & 95 & 9.9 & 2.2 & 107 & 9.3 & 2 & 2.13 & $1.97 *$ & Rejected \\
\hline Mean Score change & \multicolumn{3}{|c|}{-0.31} & \multicolumn{3}{|c|}{-0.63} & & & \\
\hline Mean Score \% change & \multicolumn{3}{|c|}{$-3.00 \%$} & \multicolumn{3}{|c|}{$-6.40 \%$} & & & \\
\hline \multicolumn{10}{|c|}{ Professional experience structure as in 2nd year graduate } \\
\hline & \multicolumn{3}{|c|}{ Accounting Students } & \multicolumn{3}{|c|}{ Management Students } & \multicolumn{3}{|c|}{ Significance } \\
\hline Subjects and means & $\mathrm{n}$ & $\begin{array}{l}\text { Mean } \\
\text { Score }\end{array}$ & $\begin{array}{c}\text { Standard } \\
\text { Deviation }\end{array}$ & $\mathrm{n}$ & $\begin{array}{l}\text { Mean } \\
\text { Score }\end{array}$ & $\begin{array}{l}\text { Standard } \\
\text { Deviation }\end{array}$ & $\mathrm{t}$ & $\mathrm{p}$ & $\begin{array}{l}\text { Hypothesis } \\
\text { Test Result }\end{array}$ \\
\hline 1st year undergraduate & 145 & 10.5 & 2.4 & 81 & 10.4 & 3.1 & 0.32 & $1.97 *$ & Confirmed \\
\hline 2nd year graduate & 95 & 10.3 & 2.5 & 107 & 10 & 2.2 & 0.9 & $1.97 *$ & Confirmed \\
\hline Mean Score change & \multicolumn{3}{|c|}{-0.21} & \multicolumn{3}{|c|}{-0.39} & & & \\
\hline Mean Score \% change & \multicolumn{3}{|c|}{$-2.00 \%$} & \multicolumn{3}{|c|}{$-3.80 \%$} & & & \\
\hline
\end{tabular}

* Significant at $\mathrm{p}<0.05$ (two-tailed).

If the work experience structure of first-year undergraduate groups persisted in the final year graduate groups then the result of $\mathrm{H} 1$ test is opposite to one initially obtained. The same procedure was applied in order to test $\mathrm{H} 1 \mathrm{a}$ and $\mathrm{H} 1 \mathrm{~b}$ under controlled work experience impact. For all equalized professional experience structures of first-year undergraduate groups and their corresponding final year graduate groups $\mathrm{H} 1 \mathrm{a}$ as well as $\mathrm{H} 1 \mathrm{~b}$ are rejected. These results reject the hypothesis that work experience does not significantly affect the questioning mind level of researched subjects (measured with HPSS).

H4: There is no statistically significant difference in mean level of questioning mind trait (measured with HPSS) between groups of researched subjects with the different length of professional experience

Aside from the area of professional experience subjects were asked to provide information on length of service (years). In H4 I expect that this independent variable has no significant influence on questioning mind level of researched subjects measured with HPSS during their university years. One-way ANOVA $(p<0.05)$ was carried out to test the significance of such impact. The mean scores of the researched subjects were divided into six groups with the respect to the length of service that subjects provided in a questionnaire. Each of six dependent variable sets was examined for significant outliers using InterQuartile Range (IQR), tested for normality with Shapiro-Wilk $(\mathrm{p}<0.05)$ and for homogeneity of variances with Levene's test $(\mathrm{p}<0.05)$. All the required assumptions to run one-way ANOVA were met. The obtained results show that the length of service does not significantly $(\mathrm{p}<0.05)$ affect the level of questioning mind measured with HPSS in the researched subjects. This finding is consistent with $\mathrm{H} 4$. 


\section{CONCLUSIONS}

The purpose of this study was to examine the impact of university programs in accounting on the students' questioning mind trait in comparison to the other academic programs in the field of economy. The relevant application of questioning mind throughout the audit process continues to be of utmost concern to the audit firms. It is also a threat identified by countless accounting departments which are in the frontline of assessing the validity of financial documentation.

By providing insight into changes of questioning mind trait mean levels that during the 5 -years university education in accounting, this study helps to address these concerns. The results indicate that standard academic program in accounting has no statistically significant impact on the questioning mind trait level in students comparing to management program. However, the researched subjects who followed the ACCA accredited program in accounting, which offered to students, had significantly increased their mean questioning mind trait level during their university education. This finding may indicate that the content and teaching methods which are both slightly different in comparison to the standard accounting program have ability to effectively shape this trait in students. It is worth underlining that the ACCA accredited program puts much more pressure on solving real life accounting problems. This fact along with finding that professional experience affects significantly the questioning mind trait mean level in both accounting and control group students suggest that facing real-life business problems may stimulate the development of this trait.

The findings presented in the study contribute not only the accounting literature, but also have implications for academic education and practice. Regulators, practitioners, and academicians generally focus on the initial (acquired) trait level when considering questioning mind. However, this study examines the possibility of efficient training it already at the university level with proper content, teaching methods and greater emphasis on solving real-life accounting/auditing problems.

This study is subject to several limitations. First, I relied on Hurtt's scale to capture individual levels of the trait. It should then be noted that this study is limited to the concept of "Questioning mind" defined by Hurtt. The questionnaire was translated into polish using a procedure consistent with the prior studies. However, there still may exist some translation inefficiencies. The study was conducted at Poznan University of Economics and Business and results of similar experimental research conducted at the other universities may vary. Future research should explore in more detail the notion of questioning mind and the method of training this trait in accounting students focusing on skeptical judgments and actions.

\section{REFERENCES}

1. AICPA, The Confirmation Process, Statement on Auditing Standards No. 67, New York 1992.

2. AICPA, Due Care in the Performance of Work. Statement on Auditing Standards No. 1, American Institute of Certified Public Accountants, New York 1997.

3. AICPA, Understanding the Entity and Its Environment and Assessing the Risks of Material Misstatement, Statement on Auditing Standards No. 109, New York 2006. 
4. Anderson B.H., Maletta M.J., Primacy Effects and the Role of Risk in Auditor BeliefRevision Processes, AUDITING: “A Journal of Practice \& Theory”, March 1999, Vol. 18, No. 1, p. 75-89.

5. Asare S.K., McDaniel L., The effect of familiarity with the preparer and task complexity on the effectiveness of the audit review process, "The Accounting Review", No. 71, April 1996, p. 139-159.

6. Baumann M., Remarks Concerning PCAOB Developments presented at the AICPA Conference on Current SEC and PCAOB Developments, December 4, Washington, DC, 2012, http://pcaobus.org/ News/Speech/Pages/12042012_AICPA.aspx.

7. Beasley M.S., Carcello J.V., Hermanson D.R., Top 10 audit deficiencies, "Journal of Accountancy", April 2001, p. 63-66.

8. Choo F., Tan K., Instruction, skepticism, and accounting students' ability to detect frauds in auditing, "The Journal of Business Education", No. 1, Fall 2000, p. 72-87.

9. Ciołek M., Professional skepticism in auditing and its characteristics, Global Challenges of Management Control and Reporting, Prace Naukowe Uniwersytetu Ekonomicznego we Wrocławiu, No. 474, 2017, p. 33-41.

10. Fogelin R.J., Pyrrhonian Reflections on Knowledge and Justification, Oxford University Press, New York 1994.

11. Grenier J.H., Encouraging Professional Skepticism in the Industry Specialization Era: A Dual-Process Model and an Experimental Test, Dissertation at the University of Illinois, 2010.

12. Harding N., Trotman K.T., Enhancing professional skepticism via the fraud brainstorming discussion outcomes, Working Paper, University of Melbourne, 2011.

13. Hult G.T.M., Ketchen D.J., Griffith D.A., Finnegan C.A., Gonzalez-Padron T., Harmancioglu N., Huang Y., Talay M.B., Cavusgil S.T., Data equivalence in cross-cultural international business research: Assessment and guidelines, "Journal of International Business Studies", No. 39 (6), 2008, p. 1027-1044.

14. Hurtt R.K., Development of a scale to measure professional skepticism, Auditing: "A Journal of Practice \& Theory", issue 29 (1), 2010, p. 149-171.

15. Hurtt R.K., Brown-Liburd H., Earley Ch., Krishnamoorthy G., Research on Auditor Professional Skepticism - Literature Synthesis and Opportunities for Future Research, AUDITING: “A Journal of Practice \& Theory”, No. 32 (Sp. 1), 2013, p. 45-97.

16. IAASB, ISA 200 Overall Objectives of the Independent Auditor and the Conduct of an Audit in Accordance with International Standards on Auditing, The International Auditing and Assurance Standards Board, New York 2010.

17. IAASB, ISA 240 The Auditor's Responsibilities Relating to Fraud in an Audit of Financial Statements, The International Auditing and Assurance Standards Board, New York, 2010.

18. KPMG, KPMG Fraud Survey 2009 Report, Kuala Lumpur 2009.

19. Kurtz P., The New Skepticism: Inquiry and Reliable Knowledge, Prometheus Books, Buffalo, NY, 1992.

20. Masztalerz M., Czy rachunkowość w Polsce jest kobieta?, Współczesne problemy w nauce, dydaktyce i praktyce rachunkowości, Prace Naukowe Uniwersytetu Ekonomicznego we Wrocławiu, No. 503, 2017, p. 326-335.

21. McCormack B., Watts T., Acquistion of Auditing Skills: Enhancing Skepticism, Problem Solving and Beyond on the Fraud Continuum, Working Paper, University Of Wollongong, 2011. 
22. McGinn M., Sense and Certainty: A Dissolution of Scepticism, Basil Blackwell Inc., New York 1989.

23. McMillan J.J., White R.A., Auditors' belief revisions and evidence search: The effect of hypothesis frame, confirmation and professional skepticism, "The Accounting Review", No. 68 (3), 1993, p. 443-465.

24. Mueller J.M., Anderson J.C., Decision aids for generating analytical review alternatives: The impact of goal framing and audit-risk level, "Behavioral Research in Accounting", No. 14, 2002, p. 157-177.

25. Nelson M., A model and literature review of professional skepticism in auditing, Auditing: "A Journal of Practice \& Theory", No. 28 (2), 2009, p. 1-34.

26. Peecher M., The influence of auditors' justification processes on their decisions: A cognitive model and experimental evidence, "Journal of Accounting Research", issue (Spring), 1996, p. 125-140.

27. Plumlee D., Rixom B.A., Rosman A.J., Training Auditors to Think Skeptically, Working paper, The University of Utah and University of Connecticut, 2012.

28. Public Company Accounting Oversight Board (PCAOB), An Audit of Internal Control over Financial Reporting Performed in Conjunction with an Audit of Financial Statements, PCAOB Auditing Standard, No. 2, 2004.

29. Rose J. M., Attention to evidence of aggressive financial reporting and intentional misstatement judgments: Effects of experience and trust, Behavioral Research in Accounting, no 19, 2007, p. 215-229.

30. Shaub M., Lawrence J., Ethics, experience and professional skepticism: A situational analysis, Behavioral Research in Accounting, issue 8 (Supplement), 1996, p. 124-157.

31. Ying S.X., Patel C., Skeptical Judgments and Self-Construal: A Comparative Study between Chinese Accounting Students in Australia and China, "Journal of International Accounting Research", Vol. 15, No. 3 (Fall), 2016, p. 97-111.

32. Zeune G.D., Fraud: It is your job!, Michigan CPA, No. 48(4), 1997, p. $26-31$.

\section{KRYTYCZNY UMYSŁ U STUDENTÓW RACHUNKOWOŚCI - BADANIE EKSPERYMENTALNE}

W trwającej debacie dotyczącej audytu na temat zawodowego sceptycyzmu „krytyczny umysł" skupił na sobie znaczącą uwagę. $Z$ tą właśnie cechą, audytorzy nie są zadowoleni z prostych odpowiedzi i szukają głębiej, dopóki w pełni nie ukształtują się ich przekonania. Stwierdzono nawet, że: ,profesjonalny sceptycyzm wymaga stałego kwestionowania tego, czy uzyskane informacje i dowody sugerują, że doszło do istotnego zniekształcenia danych w wyniku oszustwa”. Celem tego artykułu jest zbadanie, czy uniwersyteckie kierunki/ specjalności „Rachunkowość” kształtują krytyczny umysł u studentów w stopniu większym niż inne kierunki/specjalności z dziedziny ekonomii. W tym celu przeprowadziłem badanie eksperymentalne $\mathrm{z}$ wykorzystaniem jednego $\mathrm{z}$ narzędzi badawczy służących mierzeniu poziomu sceptycyzmu Hurtt Professional Skepticism Scale - HPSS. Uczestniczyło w nim 432 studentów Uniwersytetu Ekonomicznego w Poznaniu studiujących rachunkowość i zarządzanie (grupa kontrolna). Wyniki pokazały, że tylko akredytowany kierunek ACCA w zakresie rachunkowości zwiększał poziom „krytycznego myślenia” w porównaniu ze standardowym kierunkiem rachunkowości oraz kierunkiem zarządzania. Analiza wrażliwości wykazała, że płeć badanych i długość doświadczenia zawodowego nie miały statystycznie 
istotnego wpływu na wyniki. Jednakże sam fakt posiadania doświadczenia zawodowego miał wpływ na wyniki.

Słowa kluczowe: krytyczny umysł, sceptycyzm zawodowy, studiowanie rachunkowości, studenci rachunkowości, edukacja audytorska.

DOI: $10.7862 /$ rz.2018.hss.64

Tekst złożono do redakcji: czerwiec $2018 \mathrm{r}$.

Tekst przyjęto do druku: grudzień 2018 r. 